\title{
PENINGKATAN MOTIVASI BELAJAR MENGGUNAKAN \\ CONTEXTUAL TEACHING AND LEARNING DI MADRASAH IBTIDAIYAH SWASTA RAUDHATUL MUJAWWIDIN TEBO
}

\author{
Juni Astuti \\ Pendidikan Guru Madrasab Ibtidaiyah (PGMI), Fakultas Tarbiyah dan Imu Keguruan \\ Institut Agama Islam Yasni Bungo \\ E-mail:juniastuti121258@gmail.com
}

\section{Mona Novita}

Pendidikan Guru Madrasab Ibtidaiyah (PGMI), Fakultas Tarbiyah dan Ilmu Keguruan Institut Agama Islam Yasni Bungo

E-mail:monanovita@iaiyasnibungo.ac.id

\section{Syukri Ismail}

Komunikasi dan Penyiaran Islam (KPI), Fakultas Dakwah dan Komunikasi Islam Institut Agama Islam Yasni Bungo

E-mail:msyukriismail@iaiyasnibungo.ac.id

Diterima : 14 Agustus 2019

Direvisi : 24 April 2020

Diterbitkan : 30 Juni 2020

\section{Abstract}

This research was motivated by a low learning motivation of the second-grade students of MIS Raudhatul Mujawnidin on Akidah Akblak subject. The purpose of this study was to analyze the increase of students' learning motivation in the Akidah Akblak subject by using Contextual Teaching Learning (CTL) approach. The research approach was qualitative with the two-cycle action research method of Kemmis and Taggart. The results showed that: first, the level of students' learning motivation in the Akidah Akblak subject increased from 36.84 per cent to 64.69 per cent with the use of the CTL approach in the first cycle. This means that the use of CTL is a sufficient solution to overcome the low motivation of student learning, so that it remains used as an action variable for Cycle II. Second, the level of motivation of students in the Akidah Akblak subject, using the CTL approach, increased to 82.89 per cent in the second cycle. Out of the six indicators of the student's learning motivation, only one indicator is in the category of "moderately motivated," that is, the indicator of learning appreciation. This shows that the use of the CTL approach can increase the motivation of students in learning Akidah Akblak in the second class of MIS Raudhatul Mujawnidin, particularly on the material of "beriman kepada Allah." Evidence shows that almost all indicators of student motivation for learning are in the category of "bighly motivated."

Keywords: Contextual Teaching and Learning, Learning Motivation, Morals.

\section{Abstrak}

Penelitian ini dilatarbelakangi oleh rendahnya motivasi belajar siswa di kelas II MIS Raudhatul Mujawwidin pada mata pelajaran akidah akhlak. Tujuan penelitian ini adalah untuk menganalisis peningkatan motivasi belajar siswa pada mata pelajaran akidah akhlak dengan pendekatan CTL. Pendekatan penelitian yaitu kualitatif dengan metode action research melalui model Kemmis and Taggart dengan dua siklus. Hasil penelitian menunjukkan bahwa: Pertama, tingkat motivasi belajar siswa pada mata pelajaran akidah akhlak dengan pendekatan CTL di siklus I meningkat menjadi 64,69\% dari sebelumnya hanya $36,84 \%$. Hal ini berarti bahwa penggunaan pendekatan CTL cukup menjadi solusi dalam mengatasi rendahnya motivasi belajar siswa, sehingga tetap dijadikan sebagai variabel tindakan untuk siklus II. Kedua, tingkat motivasi belajar siswa pada mata pelajaran akidah akhlak dengan pendekatan CTL di siklus II meningkat menjadi $82,89 \%$. Dari keenam indikator motivasi belajar siswa, hanya satu indikator yang berada dikategori "cukup termotivasi”, yaitu indikator penghargaan dalam belajar. 
Hal ini menunjukkan bahwa penerapan pendekatan CTL dapat meningkatkan motivasi belajar siswa di kelas II MI Raudhatul Mujawwidin pada mata pelajaran akidah akhlak materi beriman kepada Allah yang dibuktikan dari hampir semua indikator motivasi belajar siswa berada pada kategori "sangat termotivasi".

Kata Kunci: Contextual Teaching and Learning, Motivasi Belajar, Akidah Akhlak

\section{Latar Belakang}

Pendidikan merupakan aset penting bagi kemajuan sebuah bangsa. Oleh karena itu setiap warga negara wajib mengikuti jenjang pendidikan, baik jenjang pendidikan sekolah dasar, pendidikan menengah maupun tinggi ${ }^{1}$ Dalam penyelenggaraan pendidikan nasional, ditegaskan bahwa

"Pendidikan adalah usaba sadar dan terencana untuk mewujudkan suasana belajar dan proses pembelajaran agar peserta didik secara aktif mengembangkan potensi dirinya untuk memiliki kekuatan spiritual keagamaan, pengendalian diri, kepribadian, kecerdasan, ablak mulia, serta keterampilan yang diperlukan dirinya, masyarakat, bangsa, dan negara". ${ }^{2}$

Oleh karena itu, seorang guru harus mampu menyesuaikan media atau model yang digunakan dalam pembelajaran agar tercipta suasana belajar dengan pendekatan student centered yaitu pembelajaran yang berpusat pada siswa sehingga siswa dapat memahami konsep pelajaran yang dipelajarinya dan mampu mengaitkannya dengan konsep situasi dunia nyata. ${ }^{3}$ Selain itu, ada empat strategi dasar dalam belajar mengajar, pertama mengidentifikasi serta

1 Meity H Idris, Strategi Pembelajaran Yang Menyenangkan (Jakarta: PT Luxima Metro Media, 2015). h. 9

2 Iskandar Agung, Panduan Penelitian Tindakan Kelas Bagi Guru (Jakarta: PT Bestari Buana Murni, 2012). h. 266.

3 Aryanti Agustina, 'Menerapkan Penggunaan Bahan Ajar Bagi Guru Di Sma Negeri 3 Ogan Komering Ulu', Journal Educative: Journal of Educational Studies, $3.1 \quad$ (2018), 16 <https://doi.org/10.30983/educative.v3i1.563>. menetapkanspesifikasi dan kualifikasi perubahan tingkah laku dan kepribadian anak didik sebagiamana yang diharapkan.Kedua, memilih sistem pendekatan belajar mengajar berdasarkan aspirasi dan pandangan hidup masyarakat. Selanjutnya, memilih dan menetapkan prosedur, metode dan teknik belajar mengajar yang dianggap paling tepat dan efektif sehingga dapat dijadikan pegangan oleh guru dalam menunaikan kegiatan mengajarnya setelah itu, menetapkan norma-norma dan batas minimal keberhasilan atau kriteria serta standar keberhasilan sehingga dapat dijadikan pedoman oleh guru dalam melakukan evaluasi hasil kegiatan belajar mengajar,yang selanjutnya akan dijadikan umpan balik untuk penyempurnaan sistem indtuksional yangbersangkutan ${ }^{4}$.

Pemerintah juga selalu merevisi kurikulum pendidikan agar selaras dan sesuai dengan perkembangan zaman begitu juga dengan model pembelajaran yang selalu dikembangkan. Model pembelajaran merupakan kerangka konseptual yang melukiskan prosedur yang sistematis dalam mengorganisasi pengalaman belajar untuk mencapai tujuan belajar tertentu. ${ }^{5}$

Kesadaran perlunya pendekatan menghubungkan antara apa yang mereka

4 Willi Afdin Otaviansa, 'Pengaruh Model Pembelajaran Ctl (Contextual Teaching And Learning) Terhadap Motivasi Dan Hasil Belajar Siswa Smkn 1 Sidoarjo', JPTM, 2.1 (2013), 35.

${ }^{5}$ Yelmi Yunarti, 'Meningkatkan Hasil Belajar Siswa Menggunakan Model Make a Match Pada Mata Pelajaran IPS Kelas IV Di SDN 11 OKU', EDUCATIVE: Journal of Educational Studies, 3.1 (2018), 88. 
pelajari dengan manfaatnya dalam kehidupan nyata dirasa sangat penting. ${ }^{6} \mathrm{Hal}$ itulah yang mendasari munculnya ide dalam penelitian ini mengingat banyaknya indikator ke arah negatif dalam kegiatan pembelajaran yang dilakukan oleh siswa kelas II MIS Rawdhatul Mujawwidin Kabupaten Tebo Provinsi Jambi. Sehingga diharapkan dengan digunakannya pendekatan CTL dapat meningkatkan motivasi belajar siswa. Sebagaimana yang disampaikan Mc. Donald bahwa motivasi merupakan perubahan energi dalam diri seseorang yang ditandai dengan munculnya "feeling"dan didahului dengan tanggapan terhadap adanya tujuan. ${ }^{7}$

Pengertian motivasi sebagai perubahan energi yang ditandai dengan munculnya rasa tapi diawali dahulu dengan adanya tanggapan terhadap tujuan. Pembelajaran CTL adalah konsep belajar yang membantu guru mengaitkan antara materi yang diajarkannya dengan situasi dunia nyata. Hal ini mendorong siswa membuat hubungan antara pengetahuan yang dimilikinya dengan penerapannya dalam kehidupan mereka sehari-hari. Motivasi dan belajar merupakan dua hal yang saling mempengaruhi. Belajar adalah perubahan tingkah laku secara relative permanen dan secara potensial terjadi sebagai hasil dari praktik penguatan (motivasi) yang dilandasi tujuan tertentu. Korelasi ini menguatkan urgensitas motivasi belajar. Hakikat motivasi belajar adalah dorongan internal dan eksternal

6 Ahmad Putra, 'Pendidikan Agama Islam Dalam Mencegah Kenakalan Siswa (Studi Kasus Di MA Muhammadiyah Lakitan Sumatera Barat)', EDUCATIVE: Journal of Educational Studies, 4.1 (2019), 82.

${ }^{7}$ Sardiman A.M, Interaksi Dan Motivasi Belajar Mengajar (Jakarta: Rajawali Press, 2014). h. 73.

${ }^{8}$ Wardani IG. AK, Persepektif Pendidikan SD (Jakarta: Universitas Terbuka, 2009). h. 26.

9 Zaenal Aqib, Model-Model, Media, Dan Strategi Pembelajaran Kontektual Inovatif (Bandung: Bandung Ymr Widya, 2013). h. 4. pada peserta didik yang sedang belajar untuk mengadakan perubahan perilaku. Motivasi belajar adalah proses member semangat belajar, arah, dan kegigihan perilaku. Artinya, perilaku yang termotivasi adalah perilaku yang penuh energi, terarah, dan bertahan lama. Guru dengan sadar merencanakan kegiatan pengajarannya secara sistematis dengan memanfaatkan segala sesuatunya guna kepentingan pengajaran. Harapan yang tidak pernah sirna dan selalu guru tuntut adalah, bagaimana bahan pelajaran yang disampaikan guru dapat dikuasai oleh anak didik secara tuntas. Ini merupakan masalah yang cukup sulit yang dirasakan guru. Kesulitan itu dikarenakan anak didik bukan hanya sebagai individu dengan segala keunikannya, tetapi mereka juga sebagai makhluk sosial dengan latar belakang yang berlainan. Paling sedikit ada tiga aspek yang membedakan anak didik yang satu dengan yang lainnya, yaitu aspek intelektual, psikologis, dan biologis ${ }^{10}$.

Pembelajaran CTL merupakan suatu konsepsi dari pembelajaran yang membantu guru atau pebelajar menghubungkan isi mata pelajaran dengan situasi yang sebenarnya dan memotivasi peserta didik untuk membuat hubungan-hubungan pengetahuan dengan penerapan didalam kehidupan mereka sehari-hari sebagai anggota keluarga, warganegara, dan pekerja. 11

Konsep CTL adalah peserta didik mampu mengaitkan antara materi yang dipelajari dengan kehidupan nyata siswa sehari-hari, sehingga pembelajaran CTL

${ }^{10}$ Srima Dewi, 'Peningkatan Motivasi Belajar Pai Siswa Melalui Metode Contextual Teaching And Learning Di Smp Bhakti Mulia Jakarta Timur' (Universitas Islam Negeri Syarif Hidayatullah Jakarta, 2014). h. 3.

${ }^{11}$ Matrinis Yamin, Strategi Dan Metode Dalam Model Pembelajaran (Ciputat: Gaung Persada Press Group, 2013). h. 52. 
mejadikan peserta didik aktif dan bertanggungjawab dalam pembelajarannya. 12

Salah satu masalah yang peneliti temukan dalam mata pelajaran akidah akhlak di kelas II MIS Raudhatul Mujawwidin adalah rendahnya motivasi belajar siswa dalam materi beriman kepada Allah. Hal itu ditandai dari beberapa indikator, seperti: (1) siswa cepat bosan jika belajar akidah akhlak, (2) siswa sering diam saat pembelajaran berlangsung, (3) siswa kadang-kadang melamun, (4) serta siswa mudah menyerah dalam menyelesaikan tugas yang diberikan oleh guru. Permasalahan demikian apabila terus menerus dibiarkan dalam proses pembelajaran akidah akhlak akan berdampak pada rendahnya motivasi belajar siswa yang kemudian berakibat pada rendahnya pencapaian hasil belajar yang diperoleh siswa nantinya.

Karena adanya fenomena inilah peneliti tertarik untuk meneliti tentang "Peningkatan Motivasi Belajar Siswa pada Mata Pelajaran Akidah Akhlak dengan Pendekatan Contextual Teachingn and Learning (CTL) di Kelas II Madrasah Ibtidaiyah Swasta Raudhatul Mujawwidin Kabupaten Tebo". Berdasarkan latar belakang masalah di atas maka rumusan masalah yang diajukan dalam penelitian adalah: "Apakah dengan penerapan pendekatan Contextual Teaching and Learning (CTL) di Kelas II Madrasah Ibtidaiyah Swasta Raudhatul Mujawwidin Kabupaten Tebo dapat meningkatkan motivasi belajar siswa pada mata pelajaran akidah akhlak?".

Sedangkan tujuan penelitian ini adalah untuk menganalisis penerapan pendekatan CTL dalam meningkatkan

12 Wahyu Susiloningsih, 'Model Pembelajaran CTL (Contextual Teaching and Learning) Dalam Meningkatkan Hasil Belajar Mahasiswa PGSD Pada Mata Kuliah Konsep IPS Dasar', Jurnal Pedagogia, 5.1 (2016), 59. motivasi belajar siswa pada mata pelajaran akidah akhlak materi beriman kepada Allah di kelas II Madrasah Ibtidaiyah Swasta Raudhatul Mujawwidin Kabupaten Tebo. Metode yang Peneliti gunakan dalam menjawab rumusan masalah tersebut adalah menggunakan metode Penelitian Tindakan Kelas model Kemmis and Taggart. Adapun langkah dari model Kemmis and Taggart ini adalah: (1) Perencanaan, (2) Tindakan dan Pengamatan, (3) Refleksi dan (4) Perencanaan Ulang. ${ }^{13}$

Teknik pengumpulan data dilakukan dengan Metode Observasi, Wawancara dan Dokumentasi. Sedangkan Teknik Analisis Data menggunakan model Milles and Huberman, yaitu Pengumpulan Data, Reduksi Data, Penyajian Data dan Penarikan Kesimpulan. ${ }^{14}$ Adapun Indikator Motivasi yang dimaksud dalam penelitian ini adalah:

1) Adanya hasrat dan keinginan berhasil

2) Adanya dorongan dan kebutuhan dalam belajar

3) Adanya harapan dan cita-cita masa depan

4) Adanya penghargaan dalam belajar

5) Adanya kegiatan yang menarik dalam kegiatan belajar

6) Adanya lingkungan belajar yang kondusif. ${ }^{15}$

Penelitian ini dikatakan berhasil apabila penggunaan pendekatan CTL dapat meningkatkan motivasi belajar siswa pada materi beriman kepada Allah di kelas II (Dua) MI Raudhatul Mujawwidin dengan motivasi memperoleh rentang $76 \%$ ke atas dari ke enam indikator motivasi belajar siswa di atas.

${ }^{13}$ Mona Novita, PTK Tidak Horor (Surabaya: Pustaka Media Guru, 2018). h. 28.

${ }^{14}$ Mumu Tanujaya, Penelitian Tindakan Kelas (Yogyakarta: Media Akademi, 2016). h. 102.

15 Hamzah B. Uno, Teori Motivasi Dan Pengukurannya (Jakarta: Bumi Aksara, 2016). h. 23. 


\section{Hasil dan Pembahasan}

\section{Temuan penelitian}

\section{a. Pra-tindakan}

Penelitian ini diawali dengan melakukan pemberian angket terhadap guru terkait motivasi belajar siswa dalam pembelajaran sebelum diterapkannya pendekatan CTL. Hasil angket yang diperoleh pada saat pembelajaran awal sebelum menggunakan CTL yaitu 50\%. Dan hasil yang diperoleh melalui tes awal sebelum adanya tindakan dengan CTL pada siswa kelas II MI Raudhatul Mujawwidin yang berjumlah 19 siswa memperoleh presentase ketuntasan 36,84\%. Berdasarkan presentase tersebut menunjukkan bahwa proses pembelajaran belum mencapai KKM yang ditetapkan yaitu 75. Dari proses tindakan pra-penelitian siswa tidak tuntas $63,15 \%$ dan siswa tuntas $36,84 \%$.

b. Siklus I pertemuan I ( 24 juli 2018)

Perencanaan

Pada tahap perencanaan peneliti menyiapkan:

(a) Membuat Rencana Pelaksanaan Pembelajaran (RPP)

(b) Peneliti menyiapkan teknik dan instrumen observasi motivasi siswa

Pelaksanaan Tindakan (action) dan Pengamatan (Observation)

Siklus I pertemuan I ini dilaksanakan pada tanggal 24 Juli 2018 pada pukul 11.30-12.30. Subjek pada penelitian tindakan ini adalah siswa kelas II MI Raudhatul Mujawwidin yang berjumlah 19 siswa. Proses pembelajaran mengacu pada RPP yang telah peneliti buat dengan validasi Dosen Pembimbing.

(a) Kegiatan pendahuluan

- Berdo'a dan salam

- Memotivasi siswa

- Menyampaikan tujuan dan (b) Kegiatan inti

- Guru menjelaskan konsep akidah akhlak materi yang diajarkan yaitu beriman kepada Allah melalui kalimat thayibah. (CTL: Konstruktivisme)

- Guru memberi kesempatan kepada siswa untuk bertanya tentang materi yang belum dimengerti. (CTL: bertanya)

Guru meminta siswa mengamati benda yang telah dibawa guru.(CTL: pemodelan dan inquiri)

- Guru meminta siswa duduk secara berkelompok untuk menyebutkan berbagai gambar orang bersyukur kemudian memberikan keterangan pada gambar.(CTL: masyarakat belajar)

- Guru meminta siswa mengisi soal yang telah disediakan

(c) Kegiatan penutup

- Siswa bersama guru mengingat kembali meteri yang telah disampaikan dan menyimpulkan materi. (CTL: refleksi)

- Guru memberikan penguatan dan kesimpulan kepada siswa

- Guru melakukan penilaian secara objektif(CTL: penilaian)

- Mengajak semua siswa berdo’a dan salam

Pada tahap observasi peneliti melakukan pengamatan pada pelaksanaan pendekatan CTL yang diberikan kepada siswa kelas II MI Raudhatul Mujawwidin sesuai dengan lembaran observasi yang sudah dibuat sebelumnya.

\section{Refleksi}

Pembelajaran tindakan siklus I pertemuan I difokuskan pada peningkatan 
motivasi belajar siswa memahami konsep beriman kepada Allah. Seluruh data yang direkam melalui observasi dan evaluasi hasil telah disusun dan didiskusikan secara bersama-sama dengan pengamat. Hasil analisis dan refleksi dari peristiwa-peristiwa yang terjadi pada tindakan siklus I pertemuan I adalah sebagai berikut:

(a) Peneliti kurang optimal dalam memanfaatkan waktu

Hal ini terjadi karena peneliti terlalu banyak menggunakan waktu untuk menjelaskan materi sehingga kesempatan untuk menanggapi pertanyaan siswa terbatas yang berdampak pada pemahaman siswa terhadap materi menjadi kurang maksimal.

(b) Peneliti masih kurang menguasai kelas. Hal ini terjadi karena belum adanya keterikatan batin antara peneliti dengan siswa dan peneliti masih terkesan kaku dalam mengajar.

(c) Siswa masih terlihat hilir mudik di dalam kelas. Hal ini dapat dilihat dari gambar di bawah ini, bahwasannya siswa dalam pembelajaran masih belum dapat duduk diam di bangku sendiri namun, masih ada siswa yang berjalan-jalan saat pembelajaran berlangsung

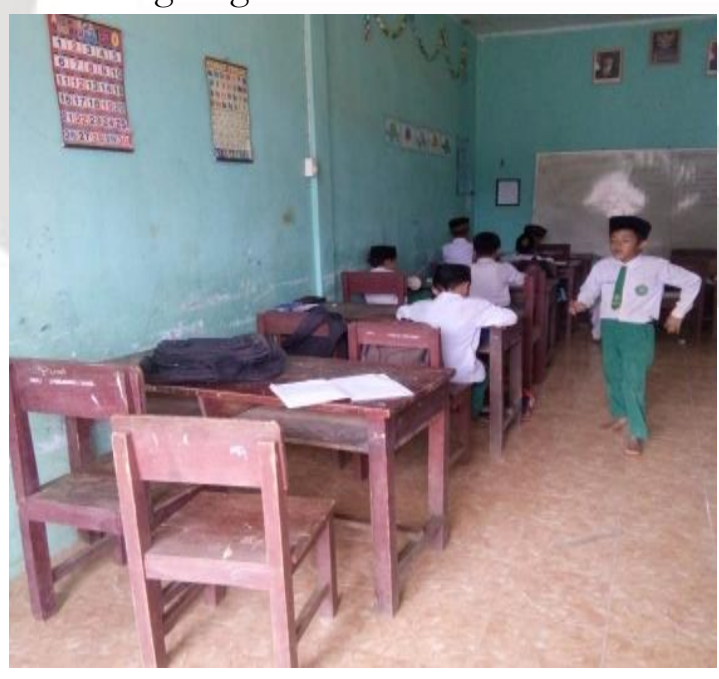

Gambar 1: Siswa masih hilir mudik selama PBM (d) Siswa kurang terfokus dalam pembelajaran. Kurang fokusnya siswa dalam pembelajaran ditandai dari banyaknya siswa yang menunduk dan menghadap kebelakang untuk mengobrol bersama temannya ketika peneliti menjelaskan pelajaran.

(e) Beberapa siswa masih belum mencapai nilai KKM yaitu 7. Hasil belajar pada siklus I pertemuan I diketahui bahwasannya dari 19 siswa 11 mencapai KKM yaitu 75 lainnya berada dibawah KKM yaitu 8 siswa. Dari proses tindakan pada siklus I pertemuan I penelitian siswa tidak tuntas $42,10 \%$ dan siswa tuntas $57,9 \%$. Hal ini belum sesuai dengan ketuntasan belajar yang diharapkan yaitu $75 \%$. Melihat kekurangankekurangan motivasi yang belum meningkat dan hasil belajar yang belum mencapai indikator keberhasilan serta siswa kurang terfokus dalam pembelajaran yang ada pada siklus I pertemuan I maka peneliti perlu melakukan perbaikan pada siklus I pertemuan II.

\section{Perencanaan Ulang}

Mengingat hasil refleksi yang terdiri dari 5 poin, ternyata poin yanag paling dominan menjadi penyebab kurang maksimalnya pelaksanaan siklus I pertemuan I ini adalah pada bagian kurangnya peneliti dalam penguasaan kelas. Hal ini disebabkan karena peneliti masih terlalu kaku dalam mengajar. Karena adanya kekurangan itu maka peneliti pada tahap ke 4 model Kemmis dan Taggrat, peneliti akan menggunakan tindakan yang baru di siklus I pertemuan II yaitu dengan menggunakan CTL yang ditambahkan dengan mempraktekkan secara langsung materi yang dipelajari. 


\section{c. Siklus I pertemuan II (31 Juli 2018) Perencanaan}

- Mengidentifikasi masalah

- Membuat Rencana Pelakanaan Pembelajaran (RPP) sesuai materi yang akan disampaikan pada siklus I pertemuan II

- Peneliti menyiapkan alat peraga dan media pembelajaran

- Peneliti menyiapkan teknik dan istrumen observasi motivasi siswa

Pelaksanaan Tindakan (Action) dan Pengamatan (Observation)

Kegiatan yang dilaksanakan pada tahap ini yaitu pengembangan rencana tindakan II dengan melaksanakan tindakan lebih meningkatkan motivasi belajar siswa dalam pelaksanaan CTL.

(a) Kegiatan inti

- Guru menjelaskan konsep akidah akhlak tentang materi yang diajarkan yaitu beriman kepada Allah melalui kalimat thayibah.(CTL: konstruktivisme)

- Guru memberi kesempatan kepada siswa untuk bertanya tentang materi yang belum dimengerti.(CTL: bertanya)

- Guru menghadirkan model berupa gambar.(CTL: pemodelan)

- Guru dan siswa mendiskusikan tentang (CTL:masyarakat belajar)

- Siswa diminta mempraktekkan pengucapan hamdalah.(CTL: inquiry)

- Guru meminta siswa mengisi soal yang telah disediakan

(b) Kegiatan Penutup

- Siswa bersama guru mengingat kembali meteri yang telah disampaikan dan menyimpulkan materi. (CTL: refleksi)

- Guru memberikan penguatan kepada siwa

- Guru melakukan penilaian secara objektif (CTL: penilaian)

- Mengajak semua siswa berdo'a dan salam

\section{Refleksi}

Berdasarkan hasil analisis data, diketahui bahwa pembelajaran tindakan siklus I pertemuan II difokuskan pada peningkatan motivasi belajar siswa memahami konsep beriman kepada Allah. Hasil analisis dan refleksi dari peristiwa-peristiwa yang terjadi pada tindakan siklus I pertemuan II adalah sebagai berikut:

(a) Peneliti kurang optimal dalam memanfatkan waktu

Hal demikian terjadi karena peneliti belum menguasai pelaksanaan pendekatan CTL.

(b) Peneliti tampak menguasai kelas Hal demikian terjadi karena peneliti dan siswa sudah mulai akrab dan ada keterikatan batin serta tidak lagi kaku dalam mengajar.

(c) Siswa terfokus pada penjelasan guru.

Pada gambar 2 dan 3, terlihat bahwa siswa terfokus dalam belajar dan semangat dalam mempraktekkan pengucapan hamdalah ketika sesudah bersin dan melaksanakan gerakan sholat. Hal ini dapat menjadikan dasar bahwasannya fokus siswa dalam belajar sudah terjadi perubahan dari siklus I pertemuan I ke siklus I pertemuan II.

Siswa yang hilir mudik sudah tidak tampak lagi

- Jumlah siswa yang masih belum mencapai nilai KKM hanya berjumlah 3 orang 


\section{Perencanaan Ulang}

Mengingat dari hasil refleksi dari lima poin di atas, ternyata poin yang paling dominan yang menyebabkan pembelajaran dengan CTL menjadi kurang maksimal adalah lemahnya peneliti dalam pemanfaatan waktu pembelajaran. Karena adanya kekurangan itu, maka peneliti akan menggunakan tindakan yang baru pada siklus II yaitu dengan pendekatan CTL menggunakan media konkret.
- Guru meminta siswa mengisi soal yang telah disediakan

(b) Kegiatan penutup

- Siswa bersama guru mengingat kembali meteri yang telah disampaikan dan menyimpulkan materi (CTL: refleksi)

- Guru melakukan penilaian secara objektif (CTL: penilaian)

- Mengajak semua siswa berdo'a dan salam

\section{d. Siklus II (7 Agustus 2018)}

\section{Perencanaan}

- Membuat Rencana Pelakanaan

Pembelajaran (RPP) sesuai materi yang akan disampaikan pada siklus I pertemuan II

- Peneliti menyiapkan alat peraga dan media pembelajaran

- Peneliti menyiapkan teknik dan instrumen observasi motivasi siswa

Pelaksanaan Tindakan (Action) dan Pengamatan (Observation)

(a) Kegiatan inti

- Guru menjelaskan konsep akidah akhlak tentang materi yang diajarkan yaitu beriman kepada Allah dengan Al Asma Al Husna (CTL: konstruktivisme)

- Guru memberi kesempatan kepada siswa untuk bertanya (CTL: bertanya)

- Guru menghadirkan model berupa tanaman kaktus (CTL: pemodelan)

- Guru dan siswa mendiskusikan tentang jawabannya (CTL: masyarakat belajar)

- Siswa diminta mengamati gambar yang disedikan guru seperti gambar burung, ikan, dan laba-laba lalu siswa menyebutkan bagaimana binatang tersebut memperoleh makanan.( CTL: inquiry)
Pada tahap observasi peneliti melakukan pengamatan pada pelaksanaan pendekatan CTL yang diberikan kepada siswa kelas II MI Raudhatul Mujawwidin dengan lembaran observasi yang sudah dipersiapkan.

\section{Refleksi}

Berdasarkan hasil analisis data, diketahui bahwa pembelajaran tindakan siklus II difokuskan pada peningkatan motivasi belajar siswa memahami konsep beriman kepada Allah. Hasil analisis dan refleksi dari peristiwa-peristiwa yang terjadi pada tindakan siklus I pertemuan II adalah sebagai berikut:

- Peneliti memanfaatkan waktu dengan baik. Hal ini terjadi karena peneliti telah memperbaiki cara menyampaikan materi sesuai kebutuhan siswa, sehingga materi dapat tercapai secara maksimal.

Peneliti dapat menguasai kelas. Siswa yang hilir mudik dari bangku satu ke bangku lainnya sudah tidak terlihat lagi seperti gambar di bawah. 


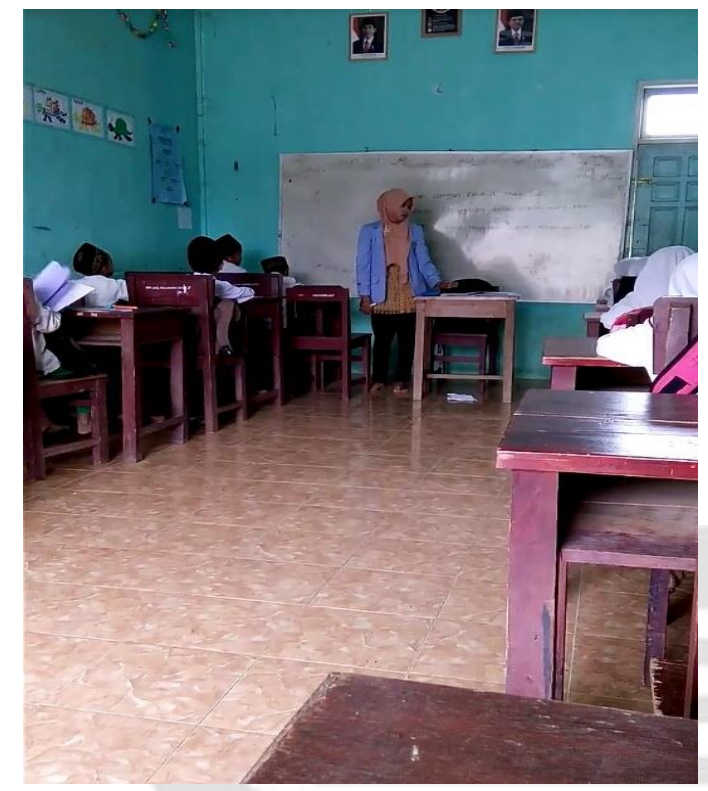

Gambar 2: Siswa sangat termotivasi dengan CTL disertai pemberian contoh konkret

Gambar 3 di bawah ini membuktikan bahwasannya penerapan CTL dalam meningkatkan motivasi belajar siswa benar-benar meningkat, hal ini dapat terlihat dari gambar bahwasannya siswa sangat memperhatikan peneliti yang bertindak sebagai guru dengan ilustrasi benda konkret dalam menjelaskan. Sehingga siswa sangat bersemangat dalam memberikan argumen atau jawaban atas pertanyaan yang peneliti lontarkan.

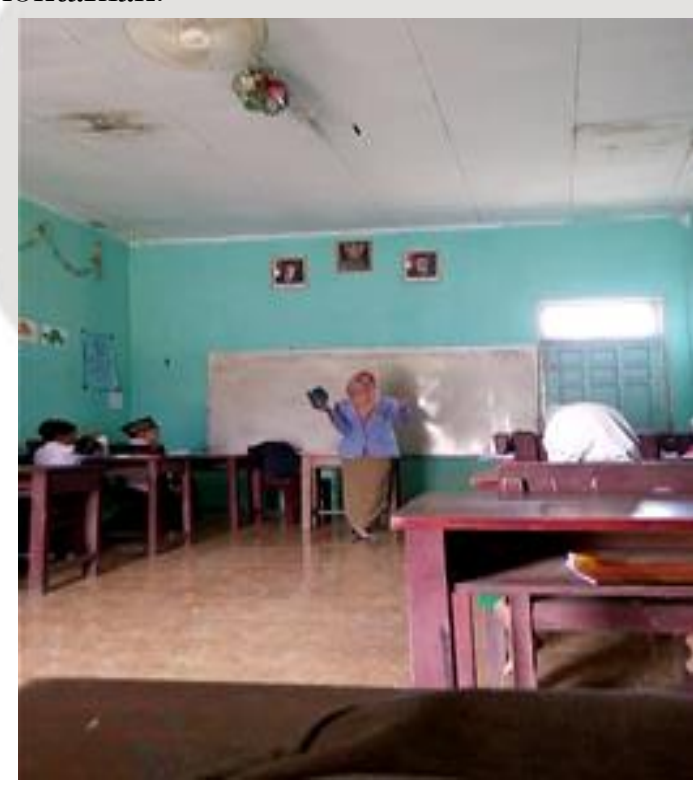

Gambar 3: Siswa Mulai Fokus

Berikut tabel motivasi belajar dan hasil belajar dari Pra siklus sampai siklus II yang menunjukkan peningkatan dengan menggunakan metode CTL.

Tabel 1. Observasi Motivasi Belajar Siswa Kelas II MI Raudhatul Mujawwidin

\begin{tabular}{|c|c|c|c|c|c|}
\hline \multirow[t]{2}{*}{ No } & \multirow[t]{2}{*}{ Indikator } & \multicolumn{4}{|c|}{ Ketercapaian } \\
\hline & & PS & SIP1 & SIP2 & S2P1 \\
\hline 1 & $\begin{array}{l}\text { Adanya } \\
\text { hasrat dan } \\
\text { keinginan } \\
\text { berhasil }\end{array}$ & 47,36 & 61,84 & 69,73 & 75,00 \\
\hline 2 & $\begin{array}{l}\text { Adanya } \\
\text { dorongan } \\
\text { dan } \\
\text { kebutuhan } \\
\text { dalam } \\
\text { belajar }\end{array}$ & 56,58 & 81,57 & 90,78 & 92,10 \\
\hline 3 & $\begin{array}{l}\text { Adanya } \\
\text { harapan dan } \\
\text { cita-cita } \\
\text { masa depan }\end{array}$ & 46,05 & 47,37 & 72,36 & 82,89 \\
\hline 4 & $\begin{array}{l}\text { Adanya } \\
\text { penghargaan } \\
\text { dalam } \\
\text { belajar }\end{array}$ & 53,94 & 64,47 & 67,10 & 69,73 \\
\hline 5 & $\begin{array}{l}\text { Adanya } \\
\text { kegiatan } \\
\text { yang } \\
\text { menarik } \\
\text { dalam } \\
\text { belajar } \\
\end{array}$ & 63,15 & 68,42 & 73,68 & 80,26 \\
\hline 6 & $\begin{array}{l}\text { Adanya } \\
\text { lingkungan } \\
\text { belajar yang } \\
\text { kondusif }\end{array}$ & 51,31 & 64,47 & 80,26 & 97,36 \\
\hline Jum & & 3183 & 3881 & 4644 & 497,3 \\
\hline Rata & rata & 53,05 & 64,69 & 75,65 & 82,89 \\
\hline
\end{tabular}

\section{Pembahasan}

Tabel 1 di atas menjelaskan bahwa yang dimaksud dengan PS adalah pra-siklus, S1P1 menjelaskan Siklus 1 pertemuan 1, S1P2 menjelaskan Siklus 1 Pertemuan 2 dan S2P1 menjelaskan Siklus 2 pertemuan 1. Adapun sub indikator dari masingmasing indikator dalam mengukur motivasi belajar siswa adalah: 1) untuk indikator Adanya hasrat dan keinginan berhasil, bentuk descriptornya adalah: Izin keluar masuk, bertanya, menanggapi pertanyaan guru dan kehadiran di dalam kelas, 2) Adanya dorongan dan kebutuhan dalam 
belajar, memiliki beberapa descriptor yaitu: Membawa buku pegangan (paket), Mencatat materi, Tepat waktu dalam pengumpulan PR, Mengerjakan tugas dengan benar, 3) Adanya harapan dan citacita masa depan, dengan descriptor: Tidak mudah bosan dalam belajar, Belajar waktu istiraahat, Masuk ruang kelas tepat waktu, Memeriksa kelengkapan tugas, 4) Adanya penghargaan dalam belajar dengan descriptor yaitu: Bertanggung jawab, Bermain di kelas saat belajar, Merespon Pr yang diberikan, Memberikan argumen dalam penyimpulan materi, 5) Adanya kegiatan yang menarik dalam belajar dengan descriptor: Bertanya kepada teman tentang materi, Belajar bersama siswa lain, Diskusi dengan teman sebangku dan Memahami penjelasan melalui contoh dan 6) Adanya lingkungan belajar yang kondusif dengan descriptor: Siap mengikuti pembelajaran, Duduk di kursi masing-masing, Tidak gelisah dalam belajar dan Menyiapkan peralatan belajar.

Tabel di atas juga menjelaskan bahwa pembelajaran dengan pendekatan CTL dapat meningkatkan motivasi belajar siswa. Hal itu terlihat dari rata-rata motivasi belajar siswa berada pada rata-rata 82,89 yang berada pada kriteria sangat termotivasi. Siswa yang memiliki indikator motivasi tertinggi terdapat pada indikator 6 yaitu adanya lingkungan belajar yang kondusif. Hal ini sesuai dengan teori peranan motivasi dalam menentukan ketekunan belajar, dimana seorang anak yang telah termotivasi untuk belajar sesuatu, akan berusaha mempelajarinya dengan baik dan tekun, dengan harapan memperoleh hasil yang lebih baik. Dalam hal itu, tampak bahwa motivasi untuk belajar menyebabkan seseorang tekun belajar. Sebaliknya, apabila seseorang kurang atau tidak memiliki motivasi untuk belajar, maka dia tidah tahan lama dalam belajar. Dia mudah tergoda untuk mengerjakan hal yang lain dan bukan belajar. Itu berarti motivasi sangat berpengaruh terhadap ketahanan dan ketekunan belajar.

Indikator motivasi belajar tertinggi kedua terdapat pada indikator ke 2 yaitu adanya dorongan dan kebutuhan dalam belajar. Hal ini sesuai dengan teori fungsi motivasi yang terdapat pada bab II bahwasannya motivasi sebagai pendorong perbuatan pada awalnya siswa tidak ada hasrat untuk belajar tetapi, karena ada sesuatu yang diinginkan maka muncullah minatnya dalam belajar. Keinginannya itu yang akhirnya mendorongnya untuk belajar. Siswa mempunyai keyakinan dan pendirian tentang apa yang seharusnya dilakukan dan sikap itulah yang mendasari serta mendorong kearah perbuatan dalam belajar. Cara pengemasan pengalaman belajar yang dirancang guru sangat berpengaruh terhadap kebermaknaan pengalaman bagi siswa ${ }^{16}$. Melalui landasan filosofi konstruktivisme, CTL menjadi alternative strategi belajar yang baru. Melalui strategi CTL, siswa diharapkan belajar melalui "mengalami" bukan "menghafal" sehingga proses pembelajaran berlangsung alamiah dalam bentuk kegiatan siswa bekerja dan mengalami, bukan mentransfer pengetahuan dari guru ke siswa. Pembelajaran kontekstual adalah konsep belajar dimana guru menghadirkan dunia nyata ke dalam kelas dan mendorong siswa membuat hubungan antara pengetahuan yang dimilikinya dengan penerapannya dalam membuat hubungan antara pengetahuan yang dimilikinya

${ }^{16}$ Dermawan A, 'Keefektifan Collaborative Learning Berbasis Quiz Edutainment Terhadap Ketuntasan Hasil Belajar', Chemistry in Education, 3.1 (2001), 57-63. 
dengan penerapannya dalam kehidupan sehari-hari ${ }^{17}$.

Indikator motivasi belajar tertinggi ketiga dari hasil penelitian adalah adanya harapan dan cita-cita masa depan. Hasil ini menunjukkan bahwa dengan penerapan metode CTL dapat meningkatkan harapan belajar serta cita-cita masa depan yang kuat pada diri siswa. Sehingga sangat direkomendasikan dalam kegiatan pembelajaran oleh guru. Terutama dalam peningkatan motivasi belajar siswa.

Dari ke-enam indikator motivasi pada tabel di atas, maka indikator dengan persentase terendah ada pada indikator "Adanya Penghargaan dalam Belajar". Ini adalah suatu fakta yang terjadi saat penelitian dilakukan. Melalui kegiatan PTK dua siklus yang dilakukan, seharusnya masih dilakukan tindakan lanjutan melihat kepada data terakhir, yaitu masih rendahnya persentase indikator adanya penghargaan dalam belajar oleh guru kepada siswa. Tindakan lanjutan tidak dilakukan mengingat keterbatasan waktu dan tenaga serta biaya peneliti. Mungkin ini bisa menjadi kajian peneliti lanjutan jika melakukan penelitian dengan metode serta permasalahan yang sama dengan peneliti ini.

Hasil penelitian peneliti ini, juga ditemukan dalam beberapa referensi terkait penggunanaan metode CTL ini guna meningkatkan motivasi belajar siswa. Sebagaimana disampaikan oleh Muliarni bahwa CTL merupakan model pembelajaran yang holistic dan bertujuan membantu mahasiswa untuk memahami makna materi ajar dengan mengaitkannya dengan konteks kehidupan mereka seharihari (konteks pribadi, social dan cultural). Sehingga mahasiswa memiliki pengetahuan

${ }^{17}$ Ida Fahru Roziyah, 'Peningkatan Motivasi Dan Hasil Belajar Melalui Contextual Teaching Learning berbantuan Study Card', Jurnal Inovasi Pendidikan Kimia, vol. 11, no. 1 (2017), pp. 1828-39. atau keterampilan yang dinamis dan fleksibel untuk mengkontruksi sendiri secara aktif pemahamanny ${ }^{18}$. CTL merupakan suatu proses pendidikan yang holistik dan bertujuan memotivasi siswa untuk memahami makna materi pelajaran yang dipelajarinya dengan mengaitkan materi tersebut dengan konteks kehidupan sehari-hari. CTL menekankan proses pembelajaran yang berlangsung alamiah dalam bentuk pengalaman siswa, bukan sekedar transfer pengetahuan dari guru ke siswa. Variasi kegiatan yang dilaksanakan dalam pembelajaran CTL sepertitanya jawab, pemodelan maupun masyarakat belajar dapat mempertinggi motivasi belajar siswa. Model CTL ini cocok untuk diterapkan di sekolah dasar karena pembelajaran yang menyenangkan sesuai dengan tahap perkembangan siswa sekolah dasar yaitu senang bermain dan baru dapat mengenal sesuatu yang bersifat konkrit ${ }^{19}$.

\section{Kesimpulan}

Simpulan penelitian ini adalah motivasi belajar di kelas II MI Raudhatul Mujawwidin pada mata pelajaran akidah akhlak materi beriman kepada Allah dengan pendekatan CTL sudah meningkat, hal ini didasarkan atas terpenuhinya ke enam indikator motivasi yaitu adanya hasrat dan keinginan berhasil, adanya dorongan dan kebutuhan dalam belajar, adanya harapan dan cita-cita masa depan, adanya penghargaan dalam belajar, adanya kegiatan

18 Muliarni, 'Peningkatan Motivasi Belajar Melalui Pendekatan Contextual Teaching and Learning (CTL) Pada Pembelajaran Bahasa Indonesia', Jurnal Penelitian Guru Indonesia-JPGI, 1.1 (2016), 26-31.

${ }^{19}$ Nila Merdeka Wati, 'Pengaruh Penerapan Model Contextual Teaching And Learning Terhadap Motivasi Belajar Ipa Siswa Kelas V Sd Negeri 1 Kebondalem Lor', Jurnal Pendidikan Guru Sekolah Dasar, vol. 11, no. 4 (2015), p. 3. 
yang menarik dalam belajar, dan adanya lingkungan belajar yang kondusif dengan rata-rata pada rentang sangat sering yang peneliti peroleh dari keempat observer yaitu dari pra siklus berada pada rata-rata 53,05\%, pada siklus I pertemuan 1 mengalami kenaikan berada pada rata-rata 64,69\%, pada siklus I pertemuan II mengalami kenaikan berada pada rata-rata $76,30 \%$ dan pada siklus II mengalami kenaikan berada pada rata-rata 82,89\% berada pada kriteria sangat termotivasi. Hal itu dapat juga dibuktikan dari nilai hasil belajar siswa pada saat pembelajaran yaitu dari pra siklus berada pada rata-rata $70,50 \%$, pada siklus I pertemuan 1 mengalami kenaikan berada pada rata-rata $72,36 \%$, pada siklus I pertemuan II mengalami kenaikan berada pada rata-rata $81,05 \%$ dan pada siklus II mengalami kenaikan berada pada rata-rata $82,10 \%$ dan telah melampaui KKM yang telah ditetapkan yaitu 75 .

\section{Saran}

Berdasarkan hasil penelitian ini, bagi pendidik dalam penerapan pendekatan CTL dapat dipersiapkan dengan baik agar pembelajaran dapat berjalan sesuai dengan rencana yang tertuang dalam RPP, selain itu para pendidik dapat menerapkan pendekatan CTL dalam pembelajaran dengan efektif dalam pembelajaran agar motivasi siswa dalam belajar meningkat. Dan yang paling terpenting, upayakan dalam pelaksanaan tindakannya, dilakukan pemberian reward agar upaya peningkatan motivasi belajar siswa benar-benar dapat dicapai.

\section{Daftar Pustaka}

\section{Buku Teks}

A.M, Sardiman, Interaksi Dan Motivasi Belajar Mengajar (Jakarta: Rajawali Press, 2014)
A, Dermawan, 'Keefektifan Collaborative Learning Berbasis Quiz Edutainment Terhadap Ketuntasan Hasil Belajar', Chemistry in Education, 3.1 (2001), 5763

Aqib, Zaenal, Model-Model, Media, Dan Strategi Pembelajaran Kontektual Inovatif (Bandung: Bandung Ymr Widya, 2013)

Agung, Iskandar, Panduan Penelitian Tindakan Kelas Bagi Guru (Jakarta: PT Bestari Buana Murni, 2012)

B. Uno, Hamzah, Teori Motivasi Dan Pengukurannya (Jakarta: Bumi Aksara, 2016)

Idris, Meity H, Strategi Pembelajaran Yang Menyenangkan (Jakarta: PT Luxima Metro Media, 2015)

IG. AK, Wardani, Persepektif Pendidikan SD (Jakarta: Universitas Terbuka, 2009)

Novita, Mona, PTK Tidak Horor (Surabaya: Pustaka Media Guru, 2018)

Tanujaya, Mumu, Penelitian Tindakan Kelas (Yogyakarta: Media Akademi, 2016)

\section{Jurnal Ilmiah}

Afdin Otaviansa, Willi, 'Pengaruh Model Pembelajaran Ctl (Contextual Teaching And Learning) Terhadap Motivasi Dan Hasil Belajar Siswa Smkn 1 Sidoarjo', JPTM, 2.1 (2013), 35

Agustina, Aryanti, 'Menerapkan Penggunaan Bahan Ajar Bagi Guru Di Sma Negeri 3 Ogan Komering Ulu', Journal Educative: Journal of Educational Studies, 3.1 (2018), 16 $<$ https://doi.org/10.30983/educativ e.v3i1.563>

Dewi, Srima, 'Peningkatan Motivasi Belajar Pai Siswa Melalui Metode Contextual Teaching And Learning Di Smp Bhakti Mulia Jakarta Timur' (Universitas Islam Negeri Syarif Hidayatullah Jakarta, 2014)

Fahru Roziyah, Ida, 'Peningkatan Motivasi Dan Hasil Belajar Melalui Contextual Teaching Learningberbantuan Study 
Card', Jurnal Inovasi Pendidikan Kimia, 11.1 (2017), 1828-39

Merdeka Wati, Nila, 'Pengaruh Penerapan Model Contextual Teaching And Learning Terhadap Motivasi Belajar Ipa Siswa Kelas V Sd Negeri 1 Kebondalem Lor', Jurnal Pendidikanguru Sekolah Dasar, 11.4 (2015), 3

Muliarni, 'Peningkatan Motivasi Belajar Melalui Pendekatan Contextual Teaching and Learning (CTL) Pada Pembelajaran Bahasa Indonesia', Jurnal Penelitian Guru Indonesia-JPGI, 1.1 (2016), 26-31

Putra, Ahmad, 'Pendidikan Agama Islam Dalam Mencegah Kenakalan Siswa (Studi Kasus Di MA Muhammadiyah Lakitan Sumatera Barat)', EDUCATIVE: Journal of Educational Studies, 4.1 (2019), 82

Susiloningsih, Wahyu, 'Model Pembelajaran CTL (Contextual Teaching and Learning) Dalam Meningkatkan Hasil Belajar Mahasiswa PGSD Pada Mata Kuliah Konsep IPS Dasar', Jurnal Pedagogia, 5.1 (2016), 59

Yamin, Matrinis, Strategi Dan Metode Dalam Model Pembelajaran (Ciputat: Gaung Persada Press Group, 2013)

Yunarti, Yelmi, 'Meningkatkan Hasil Belajar Siswa Menggunakan Model Make a Match Pada Mata Pelajaran IPS Kelas IV Di SDN 11 OKU', EDUCATIVE: Journal of Educational Studies, 3.1 (2018), 88 